\section{Fluopyram Controls Shoot-galling Caused by Pacific Shoot-gall Nematode and Improves Turf Quality in Annual Bluegrass Putting Greens}

\author{
Paweł Petelewicz ${ }^{1}$, Paweł M. Orliński ${ }^{1}$, Marco Schiavon ${ }^{2}$, \\ Manuel Mundo-Ocampo ${ }^{3}$, J. Ole Becker ${ }^{3}$, and James H. Baird ${ }^{1}$
}

AdDitional index words. Anguina pacificae, azadirachtin, Criconemella, Helicotylenchus, Meloidogyne, pacific shoot-gall disease, Poa annua

SUMMARY. Golf courses in coastal regions of northern California are often faced with severe injury caused by pacific shoot-gall nematodes (Anguina pacificae) on their annual bluegrass (Poa annua) host in putting greens. For years, fenamiphos was used for mitigating disease outbreaks until its registration was withdrawn in 2008 . An alternative product containing azadirachtin was intended for nematode suppression. Still, it required repeated applications throughout the year with questionable efficacy, making attempts to lessen the impact of the pathogen costly. This study evaluated fluopyram as a novel nematicide for control of pacific shoot-gall disease. Various application frequencies and rates were tested at several golf courses affected by the nematode. Results revealed that fluopyram applied once at $0.22 \mathrm{lb} /$ acre reduced the number of new shoot-galls and improved annual bluegrass appearance for several months. Increased rates and application frequency occasionally improved the efficacy further. Although the visual quality of turf treated with this plant protection compound was tremendously enhanced, and the number of new shoot-galls was reduced, rarely a significant effect was observed on the population density of several soil-dwelling plant-parasitic nematodes, including pacific shootgall nematode. It is hypothesized that fluopyram did not move significantly past the thatch layer and into the soil. However, it effectively reduced the ability of pacific shoot-gall nematode juveniles to induce new shoot galls. Due to its long half-life, it likely protected against both new nematode infections and dissemination of pacific shoot-gall nematode when the shoot-galls decomposed.

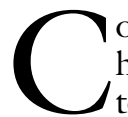

oastal northern California is home to several of America's top 100 golf courses, including

Received for publication 26 June 2020. Accepted for publication 18 Sept. 2020.

Published online 22 October 2020

${ }^{1}$ Department of Botany and Plant Sciences, 900 University Avenue, University of California, Riverside, CA 92521

${ }^{2}$ Environmental Horticulture Department, $3205 \mathrm{Col}-$ lege Ave, University of Florida, Fort Lauderdale Research and Education Center, Davie, FL 33314

${ }^{3}$ Department of Nematology, 900 University Avenue, University of California, Riverside, CA 92521

Funds to support this research were provided by the California Agricultural Experiment Station and the National Institute of Food and Agriculture, U.S. Department of Agriculture, under award number CA-R-BPS $5066-\mathrm{H}$, and Hatch projects 0164681 and 1003854 . We also thank Bayer CropScience U.S., Golf Course Superintendents Association of Northern California (GCSANC), and the California Turfgrass and Landscape Foundation (CTLF) for financial support. Special thanks go to superintendents Chris Dalhamer at Pebble Beach Golf Links, Justin Mandon at Pasatiempo Golf Club, and Dan Miller at Half Moon Bay Golf Links for hosting this research.

J.H.B. is the corresponding author. E-mail: jbaird@ ucr.edu.

This is an open access article distributed under the CC BY-NC-ND license (https://creativecommons.org/ licenses/by-nc-nd/4.0/).

https://doi.org/10.21273/HORTTECH04680-20
Cypress Point Club, Pebble Beach Golf Links, The Olympic Club, San Francisco Golf Club, Spyglass Hill Golf Course, and Monterey Peninsula Country Club (Shore and Dunes Courses) (Whitten, 2019). All of these golf courses, and many more along the coast from Carmel to Mendocino, have been affected at one time or another by pacific shoot-gall nematode (Anguina pacificae), which was first discovered in 1978 (Costello, 1983). cola, Cid Del Prado and Maggenti (1984) renamed the nematode with its current name. An endoparasitic pathogen of annual bluegrass (Poa annua), it is damaging primarily to putting greens. It infects host shoots at the base of the crown. Symptomatic galls soon develop, containing Identified initially as Anguina radici- any combination of eggs, adults, and juveniles (McClure et al., 2008). Usually two, but as many as four, generations can occur in 1 year. Second-stage juveniles (J2) can be infective to new shoots most of the year. A moisture film is essential for nematode dissemination outside the galls. The J2 move from the soil onto the young shoot surface and toward the crown (Giat et al., 2008). Usually, infection happens from spring to late fall during warmer temperatures $\left(50\right.$ to $70{ }^{\circ} \mathrm{F}$ ) and wet or foggy weather. Symptoms progress from small, yellow to brown patches that enlarge to cause a rough, uneven surface that could result in a complete turf loss (Giat et al., 2008; McClure et al., 2008).

Several golf courses affected by pacific shoot-gall disease resorted to regrassing their greens to creeping bentgrass (Agrostis stolonifera), which is considered not susceptible to the nematode, even though McClure et al. (2008) noted minor production of shoot-galls in some creeping bentgrass cultivars. More concerning is that annual bluegrass is a ubiquitous species that is well adapted to coastal climates like northern California. Without effective and selective means of controlling annual bluegrass in creeping bentgrass greens, the species quickly reinfests putting surfaces and becomes prone to pacific shoot-gall nematode-caused infection.

Plant protection against pacific shoot-gall disease has been challenging because of the lack of effective and safe nematicides. Historically, fenamiphos was the last nematicide used against this nematode, even though over time, its efficacy diminished. Eventually, the U.S. registration was withdrawn in 2008 (McClure and Schmitt, 2012). The nematicide became also the focus of regulatory action in other countries (Australian Pesticides and Veterinary Medicines Authority, 2015). As a replacement, many golf course superintendents in California resorted to using products containing azadirachtin as the active

\begin{tabular}{llll}
\hline $\begin{array}{l}\text { Units } \\
\begin{array}{l}\text { To convert U.S. to SI, } \\
\text { multiply by }\end{array}\end{array}$ & U.S. unit & SI unit & $\begin{array}{l}\text { To convert SI to U.S., } \\
\text { multiply by }\end{array}$ \\
\hline 25.4 & inch $(\mathrm{es})$ & $\mathrm{mm}$ & 0.0394 \\
0.4536 & $\mathrm{lb}$ & $\mathrm{kg}$ & 2.2046 \\
$\left({ }^{\circ} \mathrm{F}-32\right) \div 1.8$ & ${ }^{\circ} \mathrm{F}$ & ${ }^{\circ} \mathrm{C}$ & $\left({ }^{\circ} \mathrm{C} \times 1.8\right)+32$
\end{tabular}


ingredient. It is a mixture of triterpenoids extracted from seeds of the neem tree (Azadirachta indica). Azadirachtin and by-products of the neem tree have long been used as a treatment against certain fungi and insect pests as well as human diseases (Khalil, 2013). Mode of action in insects includes disruption of critical pathways needed for growth, molting, and chemoreceptors, leading to antifeeding effects [Aerts and Mordue (Luntz), 1997; Khalil, 2013; McClure et al., 2008]. McClure and Schmitt (2012) identified azadirachtin in a growth chamber bioassay as one treatment with the potential to disrupt the life cycle of pacific shootgall nematode. No nematodes were found in galls $60 \mathrm{~d}$ after treatment, and the authors hypothesized that azadirachtin either induced juveniles to stop feeding or arrested their development. Azadirachtin is environmentally safe and breaks down readily under field conditions; thus, frequent applications are usually required for efficacy (Khalil, 2013). It was suggested that it should be applied on a biweekly basis throughout the growing season, which for California means from March to November or longer (McClure and Schmitt, 2012).

Fluopyram is a pyridinyl-ethylbenzamide compound belonging to the succinate dehydrogenase inhibitor (SDHI) group of fungicides [Fungicide Resistance Action Committee (FRAC, 2020) Code No. 7] with broad-spectrum efficacy against all the stages of fungal growth. Its activity includes, but is not limited to, Ascomycetes, such as gray mold $\mathrm{Bo}^{-}$ trytis, Sclerotinia, and Monilinia species, on various crops (Veloukas and Karaoglanidis 2012). More recently, fluopyram was discovered to possess nematicidal properties (Fürsch et al., 2015). It was initially registered in cotton (Gossypium sp.) and soybean (Glycine max) as a seed- and soilapplied nematicide, often combined with the insecticide imidacloprid (Velum Total; Bayer CropScience, Research Triangle Park, NC). Fluopyram was effective against various species of plant-parasitic and freeliving nematodes (Beeman and Tylka, 2018; Faske and Hurd, 2015) but caused some phytotoxicity in soybean (Kandel et al., 2016). In southern root-knot nematode (Meloidogyne incognita) infested field trials with fresh market carrot (Daucus carota), fluopyram achieved good protection efficacy but only to the shallow depth of mechanical incorporation (Becker et al., 2019). In soil column experiments, limited downward mobility was influenced by soil type and application method (Faske and Brown, 2019).

The objectives of this research were to test fluopyram for efficacy against pacific shoot-gall disease on annual bluegrass putting greens in northern California, including rates and application frequency, compared with azadirachtin. The surveys included monitoring populations of other frequently occurring plantfeeding nematodes, such as spiral (Helicotylenchus spp.), ring (Criconemella spp.), and root-knot (Meloidogyne spp.), nematodes.

\section{Materials and methods}

Studies were conducted from 2014 to 2016 at three northern California golf courses: Pebble Beach Golf Links [Pebble Beach (lat. $36^{\circ} 33^{\prime} 43.3^{\prime \prime} \mathrm{N}$, long. $121^{\circ} 55^{\prime} 56.2^{\prime \prime} \mathrm{W}$ ); built circa 1919]; Pasatiempo Golf Club [Santa Cruz (lat. 37 $00^{\prime} 14.0^{\prime \prime} \mathrm{N}$, long. $\left.122^{\circ} 01^{\prime} 29.7^{\prime \prime} \mathrm{W}\right)$; built circa 1931], and Half Moon Bay Golf Links [Half Moon Bay (lat. $37^{\circ} 25^{\prime} 40.3^{\prime \prime} \mathrm{N}$, long. 122 $\left.26^{\prime} 19.6^{\prime \prime} \mathrm{W}\right)$; built circa 1997]. Each study area was an annual bluegrass putting green with a history of pacific shoot-gall nematode-caused disease on a root zone mix with physical properties conforming to U.S. Golf Association (USGA) recommendations. During the study, each golf course used standard cultural practices for golf course putting green maintenance. Climate data for each location during the study period are presented in Table 1. Each study's timing was based on the occurrence of nematodecaused disease symptoms or anticipation of pacific shoot-gall nematode activity considering disease history and weather conditions.

The experimental design at each location was a randomized complete block with four replications. Individual areas treated with nematicides (plots) measured $4 \times 6 \mathrm{ft}$. Nematicide treatments and application intervals are presented for all locations in Table 2 and repeated for each location in Tables 3-12. Fluopyram was applied at 0.22 or $0.44 \mathrm{lb} /$ acre a.i. [Indemnify (34.5\% fluopyram); Bayer
Environmental Science, Cary, NC]. Azadirachtin was applied at $1.19 \mathrm{lb} /$ acre a.i. [Neemix 4.5 (4.5\% azadirachtin); Certis, Columbia, MD]. Nematicide treatments were sprayed using a carbon dioxide $\left(\mathrm{CO}_{2}\right)$ backpack sprayer equipped with a fournozzle boom with 9 -inch spacing. The sprayer was equipped with flat-fan spray tips (TeeJet 8003VS; Spraying Systems Co., Wheaton, IL) that produced an output of $2 \mathrm{gal} /$ $1000 \mathrm{ft}^{2}$. All applications were made in the morning, and the experimental area was irrigated in the same evening with at least 0.1 inch of water to move products into the soil.

Nematode-caused damage [i.e., the area within an individual plot injured by nematode-induced shotgall formation $(0 \%$ to $100 \%)$ ] was assessed whenever sufficient to evaluate. When the damage was minimal, visual turf quality rating was performed. Turfgrass visual quality was rated according to the National Turfgrass Evaluation Program (NTEP) on a 1-9 scale, where $1=\operatorname{dead} ; 6=$ minimally acceptable quality; $9=$ optimum color, density, texture, and uniformity (Morris and Shearman, 1999). For enumeration of shoot galls and soil-dwelling nematodes, five soil core samples per plot were taken to a 4 -inch depth using a $7 / 8$ inch-diameter $\times 12$-inch-long soil probe, usually on the day preceding initial and sometimes sequential nematicide applications and 2-4 weeks after final applications. The exceptions were at Pebble Beach and Pasatiempo where golf course tournament and maintenance events prevented nematode sampling at the conclusion of the study. The soil samples were kept cool and expeditiously transported to the Department of Nematology facilities, University of California, Riverside. A combined method of sieving/sugar flotation and centrifugation was used to extract nematodes (Barker, 1985). Population densities of soil nematodes, including plant parasites and free living nematodes were determined according to Fleming et al., (2015). The most abundant plant-parasitic nematode species that occurred in most samples were pacific shoot-gall nematode, spiral, ring, and root-knot nematodes. University of California Integrated Pest Management (IPM) guidelines acknowledge their common 
occurrence on golf courses (Wilen et al., 2017). However, with the exception of pacific shoot-gall nematode, the significance of the others as damaging pests on cool-season grasses seems to be limited (Mitkowski, 2017). However, due to their exclusive subterranean habitat, they served as indicators of fluopyram soil penetration. Shoots and shootgalls, the disease symptoms caused by pacific shoot-gall nematode, were enumerated at 10 to $20 \times$ magnification, and number of galls per 100 shoots sampled was recorded for each plot.

All data were analyzed separately for each golf course. Turfgrass visual quality ratings were arcsine square root-transformed before analysis of variance. For the shoot-galls and nematode counts the nonparametric Kruskal-Wallis test was used. When appropriate, multiple comparisons of means were separated using Fisher's protected least significant difference test for turfgrass quality and MannWhitney $U$ test for the remaining outputs at $P=0.05$. All statistical analyses were performed in Statistica (version 10; StatSoft, Tulsa, OK).

\section{Results}

Pebble beach fluopyram and AZADIRACHTIN STUdy. Pacific shootgall disease pressure, based on visual quality, was negligible from the start of the trial until the third application of fluopyram on 7 Aug. 2014. Development of symptoms after this time was most likely caused by higher relative humidity and increase in both average air and soil temperature after July 2014 (Tables 1 and 3). However, after the third application of fluopyram, turf quality remained significantly higher in those plots compared with either azadirachtin or the untreated control. Although the differences in turf quality among treatments lasted until final evaluation on 19 Sept., the only significant difference in pacific shoot-gall nematode counts in the soil was observed on 7 Aug. and corresponded with results for turf quality (Table 4). Ectoparasitic soil-dwelling ring and spiral nematodes were not significantly reduced in plots treated with fluopyram or azadirachtin. On the other hand, the number of pacific shoot-gall nematode galls per 100 
Table 2. List of nematicide treatments, rates, and application timings used in the studies to evaluate their ability to control of pacific shoot-gall disease on annual bluegrass golf course putting greens at Pebble Beach Golf Links, Pebble Beach, CA, in 2014; Pasatiempo Golf Club, Santa Cruz, CA, in 2015-16; and Half Moon Bay Golf Links, Half Moon Bay, CA, in 2015-16.

\begin{tabular}{|c|c|c|c|c|c|c|c|}
\hline No. & Treatment & Rate $(1 \mathrm{~b} / \text { acre })^{\mathrm{z}}$ & Application timing & No. & Treatment & Rate (lb/acre) & Application timing \\
\hline \multicolumn{4}{|c|}{ Pebble Beach fluopyram and azadirachtin study ${ }^{y}$} & \multicolumn{4}{|c|}{ Pasatiempo fluopyram and azadirachtin study ${ }^{x}$} \\
\hline 1 & Untreated & & & 1 & Untreated & & \\
\hline 3 & Fluopyram & 0.44 & ACGI & 3 & Fluopyram & 0.44 & A \\
\hline \multirow[t]{3}{*}{4} & Azadirachtin & 1.19 & A-I & 4 & Fluopyram & 0.22 & $\mathrm{AC}$ \\
\hline & & & & 5 & Fluopyram & 0.44 & $\mathrm{AC}$ \\
\hline & \multicolumn{3}{|c|}{ Pasatiempo fluopyram study ${ }^{w}$} & \multicolumn{4}{|c|}{ Half Moon Bay fluopyram study } \\
\hline 1 & Untreated & & & 1 & Untreated & & \\
\hline 2 & Fluopyram & 0.44 & A & 2 & Fluopyram & 0.44 & A \\
\hline 3 & Fluopyram & 0.22 & $\mathrm{AB}$ & 3 & Fluopyram & 0.22 & $\mathrm{AB}$ \\
\hline 4 & Fluopyram & 0.22 & B-I & 4 & Fluopyram & 0.22 & B-I \\
\hline 5 & Fluopyram & 0.44 & $\mathrm{BCE}$ & 5 & Fluopyram & 0.44 & BCEF \\
\hline
\end{tabular}

${ }^{\mathrm{z}} 1 \mathrm{lb} / \mathrm{acre}=1.1209 \mathrm{~kg} \cdot \mathrm{ha}^{-1}$.

'Pebble Beach fluopyram and azadirachtin study application timings: A = 6 May 2014, B = 30 May 2014, C=13 June 2014, D = 27 June 2014, E = 11 July 2014, F= 25 July 2014, G = 8 Aug. 2014, $\mathrm{H}=22$ Aug. 2014, I = 5 Sept. 2014.

${ }^{\mathrm{x}}$ Pasatiempo fluopyram and azadirachtin study application timings: $\mathrm{A}=8 \mathrm{Dec} .2015, \mathrm{~B}=21 \mathrm{Dec} .2015, \mathrm{C}=6 \mathrm{Jan} .2016, \mathrm{D}=26 \mathrm{Jan} .2016, \mathrm{E}=1 \mathrm{Feb} .2016$.

${ }^{\mathrm{w}}$ Pasatiempo fluopyram study application timings: $\mathrm{A}=15 \mathrm{Apr} .2015, \mathrm{~B}=20 \mathrm{May} 2015, \mathrm{C}=8 \mathrm{June} 2015, \mathrm{D}=7 \mathrm{July} 2015, \mathrm{E}=5 \mathrm{Aug}$. $2015, \mathrm{~F}=3 \mathrm{Sept} .2015, \mathrm{G}=30 \mathrm{Sept}$. $2015, \mathrm{H}=26$ Oct. $2015, \mathrm{I}=30$ Nov. 2015.

${ }^{v}$ Half Moon Bay fluopyram application timings: A = 15 Apr. 2015, B = 20 May 2015, C = 8 June 2015, D = 7 July 2015, E = 5 Aug. 2015 , F = 3 Sept. 2015, G= 1 Oct. 2015, $\mathrm{H}=27$ Oct. 2015 , I = 1 Dec. 2015 .

Table 3. The impact of fluopyram and azadirachtin on turfgrass visual quality of nematode-infested annual bluegrass putting green at Pebble Beach Golf Links, Pebble Beach, CA, in 2014.

\begin{tabular}{|c|c|c|c|c|c|c|c|c|c|c|c|c|c|}
\hline \multirow[b]{4}{*}{ No. } & \multirow[b]{4}{*}{ Treatment } & \multirow{4}{*}{$\begin{array}{c}\text { Rate } \\
(\mathrm{lb} / \text { acre })^{\mathrm{z}}\end{array}$} & \multirow{4}{*}{$\begin{array}{c}\text { Application } \\
\text { timing }^{\mathrm{y}}\end{array}$} & \multicolumn{10}{|c|}{ Data collection date } \\
\hline & & & & \multicolumn{2}{|c|}{ May } & \multicolumn{2}{|c|}{ June } & \multicolumn{2}{|c|}{ July } & \multicolumn{2}{|c|}{ August } & \multicolumn{2}{|c|}{ September } \\
\hline & & & & 16 & 29 & 11 & 27 & 11 & 25 & 7 & 20 & 4 & 19 \\
\hline & & & & \multicolumn{10}{|c|}{ 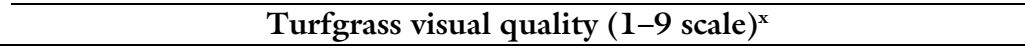 } \\
\hline 1 & Untreated & & & $6.3^{\mathrm{w}}$ & 6.8 & 6.8 & 4.5 & 6.5 & 6.8 & 7.3 & $4.6 \mathrm{c}$ & $4.8 \mathrm{~b}$ & $4.3 \mathrm{~b}$ \\
\hline 2 & Fluopyram & 0.22 & ACGI & 6.0 & 6.5 & 7.0 & 5.3 & 7.0 & 7.3 & 8.0 & $7.4 \mathrm{~b}$ & $6.8 \mathrm{a}$ & $7.5 \mathrm{a}$ \\
\hline 3 & Fluopyram & 0.44 & ACGI & 6.3 & 7.0 & 6.9 & 4.8 & 7.1 & 7.3 & 8.0 & $8.1 \mathrm{a}$ & $7.8 \mathrm{a}$ & $8.3 \mathrm{a}$ \\
\hline
\end{tabular}

shoots was significantly lower than in the untreated control and azadirachtin-treated plots on 7 and 20 Aug. 2014 (Table 4).

Pasatiempo fluopyram and AZADIRACHTIN STUDY. Compared with the Pebble Beach study, pacific shoot-gall nematode was present at the start of the experiment in Dec. 2015 due in part to ideal weather conditions (rainfall in Nov. 2015) for annual bluegrass infections by the nematode (Tables 1 and 5 ). All fluopyram treatments were effective in reducing nematode-caused turf damage; however, sequential applications were in general more effective than single ones.

Although there were no statistically significant differences between low and high rate of fluopyram when applied once, nematode damage ratings were numerically always lower with the higher rate and significant differences were observed on 26 Jan. and 12 Apr. in sequential applications. Azadirachtin also resulted in reduced injury compared with untreated control starting from 27 Feb. (Table 5). No shoot-gall counts were taken in this study, and tournament events at the golf course did not allow for a final sampling of nematodes in the soil. None of the population nematode soil counts were different among treatments (Table 6).

Pasatiempo fluopyram study. A separate study was conducted comparing fluopyram rates and timing of applications on a different putting green at Pasatiempo from Apr. 2015 to Feb. 2016. Although pacific shootgall nematode-caused annual bluegrass damage was minimal at the start of the study, either one or two 
Table 4. The impact of fluopyram and azadirachtin on the number of pacific shoot-gall (PSGN), ring (RN), and spiral (SN) nematodes separated by species in $100 \mathrm{~mL}\left(6.1 \mathrm{inch}^{3}\right)$ of soil and on the number of PSGN galls counted per 100 annual bluegrass shoots at Pebble Beach Golf Links, Pebble Beach, CA, in 2014.

\begin{tabular}{|c|c|c|c|c|c|c|c|}
\hline \multirow[b]{3}{*}{ No. } & \multirow[b]{3}{*}{ Treatment } & \multirow{3}{*}{$\begin{array}{c}\text { Rate } \\
(\text { lb/acre })^{z}\end{array}$} & \multirow{3}{*}{$\begin{array}{c}\text { Application } \\
\text { timing }^{\mathrm{y}}\end{array}$} & \multicolumn{4}{|c|}{ Sample collection date } \\
\hline & & & & 16 May & 11 June & 7 Aug. & 20 Aug. \\
\hline & & & & \multicolumn{4}{|c|}{ PSGN (no./100 mL of soil) ${ }^{\mathrm{z}}$} \\
\hline 2 & Fluopyram & 0.22 & ACGI & 255 & 353 & $18 \mathrm{~b}$ & 30 \\
\hline 3 & Fluopyram & 0.44 & ACGI & 275 & 155 & $18 \mathrm{~b}$ & 35 \\
\hline 4 & Azadirachtin & 1.19 & A-I & 238 & 323 & $270 \mathrm{a}$ & 88 \\
\hline 1 & Untreated & & & $138^{x}$ & 180 & 40 & 78 \\
\hline 2 & Fluopyram & 0.22 & ACGI & 188 & 108 & 23 & 35 \\
\hline 3 & Fluopyram & 0.44 & ACGI & 288 & 220 & 48 & 40 \\
\hline \multirow[t]{2}{*}{4} & Azadirachtin & 1.19 & A-I & 213 & 215 & 63 & 50 \\
\hline & & & & \multicolumn{4}{|c|}{$\mathrm{SN}($ no. $/ 100 \mathrm{~mL}$ of soil) } \\
\hline & & & & & & \multicolumn{2}{|c|}{$\begin{array}{c}\text { PSGN galls (no./100 } \\
\text { shoots) }\end{array}$} \\
\hline 1 & Untreated & & & & & $63 a^{z}$ & $146 \mathrm{a}$ \\
\hline 2 & Fluopyram & 0.22 & ACGI & & & $7 \mathrm{~b}$ & $7 \mathrm{~b}$ \\
\hline 3 & Fluopyram & 0.44 & ACGI & & & $3 \mathrm{~b}$ & $3 \mathrm{~b}$ \\
\hline 4 & Azadirachtin & 1.19 & A-I & & & $57 \mathrm{a}$ & $108 \mathrm{a}$ \\
\hline
\end{tabular}

${ }^{\mathrm{z}} 1 \mathrm{lb} /$ acre $=1.1209 \mathrm{~kg} \cdot \mathrm{ha}^{-1}, 1$ nematode $/ 100 \mathrm{~mL}=0.1639$ nematode $/$ inch $^{3}$.

${ }^{\mathrm{y}}$ Application timings: $\mathrm{A}=6$ May, $\mathrm{B}=30$ May, $\mathrm{C}=13$ June, $\mathrm{D}=27$ June, $\mathrm{E}=11$ July, $\mathrm{F}=25$ July, $\mathrm{G}=8 \mathrm{Aug}$., $\mathrm{H}=22 \mathrm{Aug}$., $\mathrm{I}=5 \mathrm{Sept}$.

${ }^{x}$ Means within a column followed by the same letter or not followed by any letter are not statistically different at $P \leq 0.05$ according to Mann-Whitney $U$ test.

Table 5. The impact of fluopyram and azadirachtin on turfgrass damage caused by nematodes on an annual bluegrass chipping green at Pasatiempo Golf Club, Santa Cruz, CA, in 2015-16.

\begin{tabular}{|c|c|c|c|c|c|c|c|c|c|c|}
\hline \multirow[b]{4}{*}{ No. } & \multirow[b]{4}{*}{ Treatment } & \multirow{4}{*}{$\begin{array}{c}\text { Rate } \\
(\text { lb } / \text { acre })^{z}\end{array}$} & \multirow{4}{*}{$\begin{array}{c}\text { Application } \\
\text { timing }^{\mathrm{y}}\end{array}$} & \multicolumn{7}{|c|}{ Data collection date } \\
\hline & & & & \multirow{3}{*}{$\frac{2015}{8 \text { Dec. }}$} & \multicolumn{6}{|c|}{2016} \\
\hline & & & & & 6 Jan. & 26 Jan. & 1 Feb. & 27 Feb. & 18 Mar. & 12 Apr. \\
\hline & & & & & \multicolumn{5}{|c|}{ Turfgrass damage caused by nematodes (\%) } & \\
\hline 1 & Untreated & & & $28.8^{\mathrm{x}}$ & 45.0 & $52.5 \mathrm{a}$ & $56.3 \mathrm{a}$ & $68.8 \mathrm{a}$ & $62.5 \mathrm{a}$ & $60.0 \mathrm{a}$ \\
\hline 2 & Fluopyram & 0.22 & A & 30.0 & 22.5 & $22.5 \mathrm{bc}$ & $28.8 \mathrm{abc}$ & $25.0 \mathrm{~b}$ & $36.3 \mathrm{ab}$ & $26.3 \mathrm{a}$ \\
\hline 3 & Fluopyram & 0.44 & A & 32.5 & 27.5 & $18.0 \mathrm{abc}$ & $27.5 \mathrm{ab}$ & $15.0 \mathrm{~b}$ & $28.8 \mathrm{ab}$ & $15.8 \mathrm{abc}$ \\
\hline 6 & Azadirachtin & 1.19 & A-E & 23.8 & 31.3 & $40.0 \mathrm{ab}$ & $32.5 \mathrm{abc}$ & $13.8 \mathrm{~b}$ & $18.8 \mathrm{~b}$ & $10.0 \mathrm{~b}$ \\
\hline
\end{tabular}

${ }^{\mathrm{z}} \mathrm{l} \mathrm{lb} / \mathrm{acre}=1.1209 \mathrm{~kg} \cdot \mathrm{ha}^{-1}$.

yApplication timings: $\mathrm{A}=8$ Dec. 2015, $\mathrm{B}=21$ Dec. 2015, C = 6 Jan. 2016, D = 26 Jan. 2016, E = 1 Feb. 2016.

${ }^{\mathrm{x}}$ Means within a column followed by the same letter or not followed by any letter are not statistically different at $P \leq 0.05$ according to Mann-Whitney $U$ test.

applications of fluopyram (treatments $2-5$ ) increased turf quality on the 20 May and 8 June rating dates (Table 7). It should be noted that pacific shoot-gall nematode counts were significantly lower for those treatments on the 6 July sampling compared with the untreated control (Table 9). There were no effects of any treatment on population levels of any other nematodes. Furthermore, turf quality and fluopyram applications leading up to 6 July corresponded with the number of galls per 100 shoots (Table 8). Looking collectively at all data up to $6 \mathrm{July}$, it appeared that two applications of fluopyram at the lower rate were slightly more effective than just one application at a higher rate. Pacific shoot-gall disease activity subsided again from August to October. Additionally, some rating and sampling dates corresponded with aeration and sand topdressing on the study area, reflecting lower quality ratings for all treatments (Table 7). Nevertheless, pacific shoot-gall disease-caused injury increased again in late October, and treatments 6 and 7 were planned to commence once turfgrass damage became evident in the fall. As in the spring, fluopyram treatments (this time 2-7) improved 
Table 6. The impact of fluopyram and azadirachtin on the number of pacific shoot-gall (PSGN), ring (RN), spiral (SN), and root-knot $(\mathrm{RKN})$ nematodes separated by species in $100 \mathrm{~mL}\left(6.1 \mathrm{inch}^{3}\right)$ of soil collected from an annual bluegrass chipping green at Pasatiempo Golf Club, Santa Cruz, CA, in 2015-16.

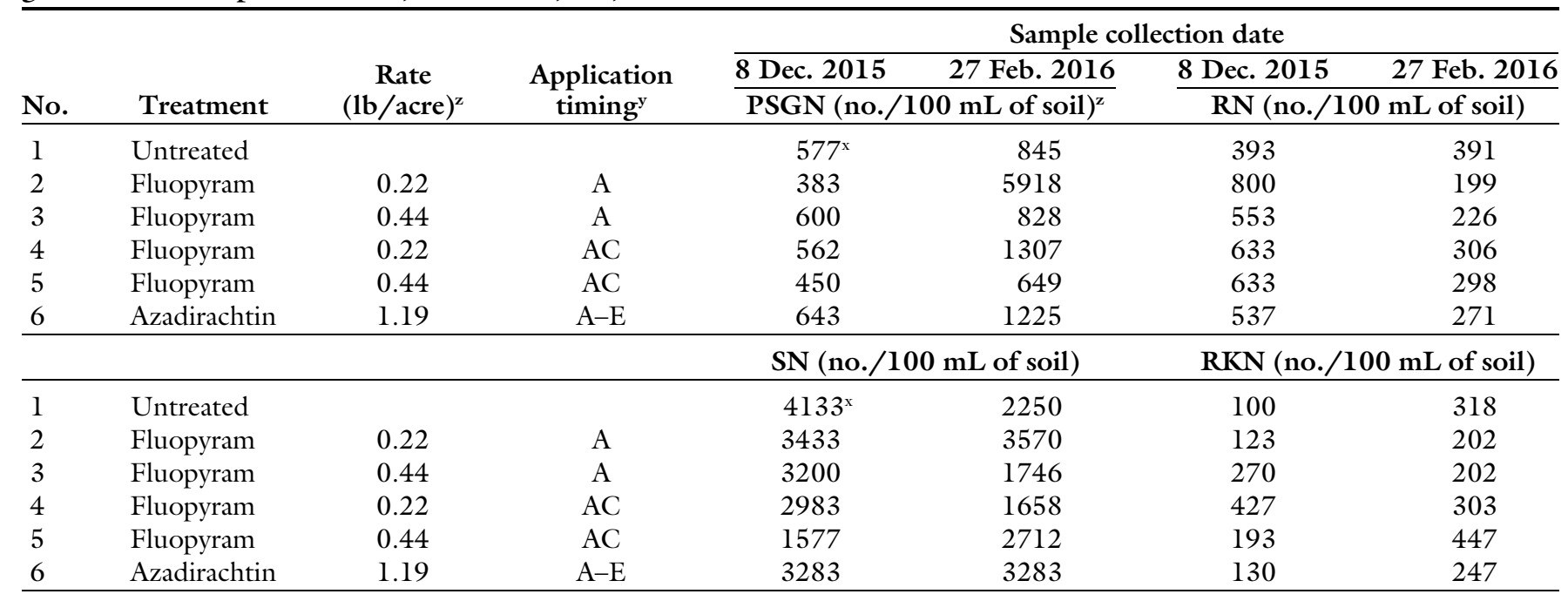

${ }^{\mathrm{z}} 1 \mathrm{lb} / \mathrm{acre}=1.1209 \mathrm{~kg} \cdot \mathrm{ha}^{-1}, \mathrm{l}$ nematode $/ 100 \mathrm{~mL}=0.1639$ nematode $/$ inch $^{3}$.

${ }^{y}$ Application timings: $\mathrm{A}=8$ Dec. 2015, $\mathrm{B}=21$ Dec. 2015, C = 6 Jan. 2016, D = 26 Jan. 2016, E = 1 Feb. 2016.

${ }^{\mathrm{x}}$ Means within a column followed by the same letter or not followed by any letter are not statistically different at $P \leq 0.05$ according to Mann-Whitney $U$ test.

Table 7. The impact of fluopyram on turfgrass visual quality of nematode-infested annual bluegrass putting green at Pasatiempo Golf Club, Santa Cruz, CA, in 2015-16.

\begin{tabular}{|c|c|c|c|c|c|c|c|c|c|c|c|c|}
\hline \multirow[b]{4}{*}{ No. } & \multirow[b]{4}{*}{ Treatment } & \multirow{4}{*}{$\begin{array}{c}\text { Rate } \\
(\mathrm{lb} / \text { acre })^{\mathrm{z}}\end{array}$} & \multirow{4}{*}{$\begin{array}{c}\text { Application } \\
\text { timing }^{\mathbf{y}}\end{array}$} & \multicolumn{9}{|c|}{ Data collection date } \\
\hline & & & & \multicolumn{8}{|c|}{2015} & \multirow{2}{*}{$\frac{2016}{6 \text { Jan. }}$} \\
\hline & & & & 15 Apr. & 20 May & 8 June & 6 July & 5 Aug. & 2 Sept. & 30 Sept. & 8 Dec. & \\
\hline & & & & \multicolumn{9}{|c|}{ Turfgrass visual quality (1-9 scale $)^{x}$} \\
\hline 1 & Untreated & & & $7.0^{\mathrm{w}}$ & $6.0 \mathrm{c}$ & $6.0 \mathrm{de}$ & 8.3 & 6.8 & 6.3 & 4.5 & $4.8 \mathrm{~d}$ & $4.5 \mathrm{~b}$ \\
\hline 2 & Fluopyram & 0.44 & A & 7.0 & $7.8 \mathrm{ab}$ & $8.5 \mathrm{ab}$ & 8.5 & 7.3 & 6.0 & 4.3 & $7.0 \mathrm{bc}$ & $6.8 \mathrm{a}$ \\
\hline 3 & Fluopyram & 0.22 & $\mathrm{AB}$ & 7.0 & $8.0 \mathrm{a}$ & $8.8 \mathrm{a}$ & 8.5 & 7.5 & 6.8 & 4.8 & $8.3 \mathrm{a}$ & $7.3 \mathrm{a}$ \\
\hline 6 & Fluopyram & 0.44 & $\mathrm{H}$ & 7.0 & $6.3 \mathrm{c}$ & $5.0 \mathrm{e}$ & 8.0 & 7.0 & 6.3 & 4.5 & $7.3 \mathrm{abc}$ & $7.3 \mathrm{a}$ \\
\hline 7 & Fluopyram & 0.22 & $\mathrm{HI}$ & 7.0 & $6.5 \mathrm{bc}$ & $6.0 \mathrm{de}$ & 8.3 & 6.8 & 6.3 & 3.8 & $6.3 c$ & $6.8 \mathrm{a}$ \\
\hline
\end{tabular}

${ }^{\mathrm{z}} \mathrm{l} \mathrm{lb} / \mathrm{acre}=1.1209 \mathrm{~kg} \cdot \mathrm{ha}^{-1}$.

${ }^{y}$ Application timings: A = 15 Apr. 2015, B = 20 May 2015, C = 8 June 2015, D = 7 July 2015, E = 5 Aug. 2015, F= 3 Sept. 2015, G = 30 Sept. 2015, H = 26 Oct. 2015, I = 30 Nov. 2015.

${ }^{\mathrm{x}} \mathrm{l}=$ dead; 6 = minimally acceptable quality; 9 = optimal color, density, texture, and uniformity.

${ }^{\mathrm{w}}$ Means within a column followed by the same letter or not followed by any letter are not statistically different at $P \leq 0.05$ according to Fisher's protected least significant difference test.

turf quality in both December and January compared with the untreated control. Another aeration and sand topdressing event precluded final quality ratings in February. The last nematode counts revealed no pacific shoot-gall nematodes in plots treated with fluopyram either two or eight times with $0.22 \mathrm{lb} /$ acre starting at or near the beginning of the trial. There were no treatment effects on any other nematodes for any sampling date (Table 9).

Half Moon Bay fluopyram STUdy. The study at Half Moon Bay was conducted mostly on the same dates as Pasatiempo, and most treatments were repeated in space and time except for treatments 5-7. Relative to Pasatiempo, which is more inland $(\approx 2.8$ miles from the Pacific Ocean), the putting green at Half Moon Bay was less than 100 yards from ocean. Thus, pacific shoot-gall nematode pressure was higher, occurred earlier, and was more chronic in the Half Moon Bay study due to favorable environmental conditions (Tables 1 and 10). Hence, treatment 5 received a fourth application relative to three at Pasatiempo, and treatments 6 and 7 were initiated in $\mathrm{Au}^{-}$ gust and September relative to October and November for Pasatiempo in response to increasing putting green damage. Initial applications of fluopyram did not significantly improve turf quality leading up to the 6 July root and shoot/gall sampling date. However, a significant decrease in galls/100 shoots, as well as pacific shoot-gall nematode counts in soil on 2 Feb., compared with untreated control, were the best indication of fluopyram 
efficacy (Tables 11 and 12). There were no treatment effects on any other nematode for any sample date (Table 12). In general, turf quality decreased in all plots through the remainder of summer and fall. It was not until December through the end of the study in February that significant improvements in turf quality were seen with fluopyram treatments relative to the untreated control (Table 10). In this situation, more applications of fluopyram (eight at 0.22 $\mathrm{lb} / \mathrm{acre}$ and four at $0.44 \mathrm{lb} / \mathrm{acre}$ for treatments 4 and 5 , respectively) were needed to provide the highest turf quality. Applications made later in the study (treatments 6 and 7) were not significantly different from the treatments mentioned earlier. All fluopyram treatments suppressed the soil population of pacific shoot-gall nematode below the detection level at the end of the study. In contrast, nematode counts were very high in the control plots. Finally, counts of other plant-parasitic nematodes (ring, spiral, and root-knot) were once again

Table 8. The impact of fluopyram on the number of pacific shoot-gall nematode (PSGN) galls counted per 100 shoots collected from an annual bluegrass putting green at Pasatiempo Golf Club, Santa Cruz, CA, in 2015.

\begin{tabular}{|c|c|c|c|c|c|}
\hline \multirow[b]{3}{*}{ No. } & \multirow[b]{3}{*}{ Treatment } & \multirow[b]{3}{*}{$\begin{array}{c}\text { Rate } \\
(\text { lb/acre })^{\mathrm{z}}\end{array}$} & \multirow[b]{3}{*}{$\begin{array}{l}\text { Application } \\
\text { timing }^{\mathrm{y}}\end{array}$} & \multicolumn{2}{|c|}{$\begin{array}{c}\text { Samples collection } \\
\text { date }\end{array}$} \\
\hline & & & & 15 Apr. & 6 July \\
\hline & & & & \multicolumn{2}{|c|}{$\begin{array}{c}\text { PSGN galls } \\
\text { (no./100 shoots) }\end{array}$} \\
\hline 1 & Untreated & & & $5^{x}$ & $8 \mathrm{a}$ \\
\hline 2 & Fluopyram & 0.44 & A & 3 & $0 \mathrm{~b}$ \\
\hline 3 & Fluopyram & 0.22 & $\mathrm{AB}$ & 6 & $0 \mathrm{~b}$ \\
\hline 4 & Fluopyram & 0.22 & B-I & 4 & $0 \mathrm{~b}$ \\
\hline 5 & Fluopyram & 0.44 & $\mathrm{BCE}$ & 4 & $0 \mathrm{~b}$ \\
\hline
\end{tabular}

${ }^{\mathrm{z}} 1 \mathrm{lb} / \mathrm{acre}=1.1209 \mathrm{~kg} \cdot \mathrm{ha}^{-1}$.

${ }^{y}$ Application timings: $\mathrm{A}=15$ Apr. 2015, B $=20$ May 2015, C = 8 June 2015, D = 7 July 2015, E = 5 Aug. 2015, F = 3 Sept. 2015, G = 30 Sept. 2015, H = 26 Oct. 2015, I = 30 Nov. 2015.

${ }^{x}$ Means within a column followed by the same letter or not followed by any letter are not statistically different at $P \leq$ 0.05 according to Mann-Whitney $U$ test.

not different from the untreated control (Table 12).

\section{Discussion}

Pacific shoot-gall nematode has been a troublesome nematode for more than 40 years on coastal northern California golf courses with annual bluegrass putting greens. With significant turf losses and adverse effects on playing conditions, some golf courses changed to more pacific shoot-gall disease-resistant creeping bentgrass. Still, environmental conditions quickly allow reinvasion of annual bluegrass and resultant susceptibility to nematode activity. Fenamiphos was the most widely used product for managing pacific shootgall disease until registration was withdrawn in 2008. Without any other registered, effective alternatives, golf course superintendents resorted to using a product containing azadirachtin, which was labeled for insect control but not as a nematicide. It was costly, required frequent applications, and provided at best anecdotal efficacy against pacific shoot-gall nematode. The present study's results confirmed no significant activity of azadirachtin against pacific shoot-gall nematode or any of the other recovered nematodes with

Table 9. The impact of fluopyram on the number of pacific shoot-gall (PSGN), ring (RN), spiral (SN), and root-knot (RKN) nematodes separated by species in $100 \mathrm{~mL}\left(6.1 \mathrm{inch}^{3}\right)$ of soil collected from annual bluegrass putting green at Pasatiempo Golf Club, Santa Cruz, CA, in 2015-16.

\begin{tabular}{|c|c|c|c|c|c|c|c|c|c|}
\hline \multirow[b]{4}{*}{ No. } & \multirow[b]{4}{*}{ Treatment } & \multirow{4}{*}{$\begin{array}{c}\text { Rate } \\
(\mathrm{lb} / \text { acre })^{\mathrm{z}}\end{array}$} & \multirow{4}{*}{$\begin{array}{c}\text { Application } \\
\text { timing }^{\mathrm{y}}\end{array}$} & \multicolumn{6}{|c|}{ Sample collection date } \\
\hline & & & & \multicolumn{2}{|c|}{2015} & 2016 & \multicolumn{2}{|c|}{2015} & 2016 \\
\hline & & & & 15 Apr. & 6 July & $\overline{2 \mathrm{Feb} .}$ & 15 Apr. & 6 July & $2 \mathrm{Feb}$. \\
\hline & & & & \multicolumn{3}{|c|}{ PSGN (no./100 mL of soil) $)^{\mathrm{z}}$} & \multicolumn{3}{|c|}{ RN (no./100 mL of soil) } \\
\hline 1 & Untreated & & & $15^{x}$ & $263 \mathrm{a}$ & 167 & 71 & 85 & 63 \\
\hline 2 & Fluopyram & 0.44 & A & 20 & $18 \mathrm{~b}$ & 53 & 80 & 66 & 77 \\
\hline 3 & Fluopyram & 0.22 & $\mathrm{AB}$ & 83 & $0 \mathrm{~b}$ & 0 & 12 & 13 & 86 \\
\hline 6 & Fluopyram & 0.44 & $\mathrm{H}$ & 19 & - & 217 & 70 & - & 157 \\
\hline \multirow[t]{2}{*}{7} & Fluopyram & 0.22 & $\mathrm{HI}$ & 63 & - & 299 & 68 & - & 63 \\
\hline & & & & \multicolumn{3}{|c|}{$\mathrm{SN}($ no. $/ 100 \mathrm{~mL}$ of soil) } & \multicolumn{3}{|c|}{ RKN (no./100 mL of soil) } \\
\hline 1 & Untreated & & & $1730^{\mathrm{x}}$ & 708 & 2437 & 78 & 73 & 83 \\
\hline 2 & Fluopyram & 0.44 & A & 1205 & 563 & 3056 & 26 & 0 & 11 \\
\hline 6 & Fluopyram & 0.44 & $\mathrm{H}$ & 2193 & - & 3250 & 0 & - & 157 \\
\hline 7 & Fluopyram & 0.22 & $\mathrm{HI}$ & 2245 & - & 3358 & 8 & - & 60 \\
\hline
\end{tabular}

${ }^{\mathrm{z}} 1 \mathrm{lb} /$ acre $=1.1209 \mathrm{~kg} \cdot \mathrm{ha}^{-1}, \mathrm{l}$ nematode $/ 100 \mathrm{~mL}=0.1639$ nematode $/ \mathrm{inch}^{3}$.

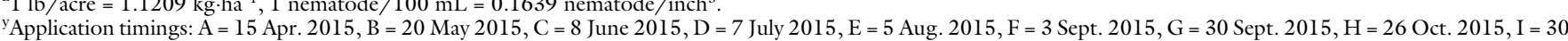
Nov. 2015

${ }^{\mathrm{x}}$ Means within a column followed by the same letter or not followed by any letter are not statistically different at $P \leq 0.05$ according to Mann-Whitney $U$ test. 
Table 10. The impact of fluopyram on turfgrass visual quality of nematode-infested annual bluegrass putting green at Half Moon Bay Golf Links, Half Moon Bay, CA, in 2015-16.

\begin{tabular}{|c|c|c|c|c|c|c|c|c|c|c|c|c|}
\hline \multirow[b]{4}{*}{ No. } & \multirow[b]{4}{*}{ Treatment } & \multirow{4}{*}{$\begin{array}{c}\text { Rate } \\
(\text { lb/acre })^{z}\end{array}$} & \multirow{4}{*}{$\begin{array}{c}\text { Application } \\
\text { timing }^{\mathrm{y}}\end{array}$} & \multicolumn{9}{|c|}{ Data collection date } \\
\hline & & & & \multicolumn{8}{|c|}{2015} & \multirow{2}{*}{$\frac{2016}{2 \text { Feb. }}$} \\
\hline & & & & 15 Apr. & 20 May & 8 June & 6 July & 5 Aug. & l Sept. & l Oct. & 8 Dec. & \\
\hline & & & & \multicolumn{9}{|c|}{ Turfgrass visual quality (1-9 scale $)^{x}$} \\
\hline 1 & Untreated & & & $6.8^{\mathrm{w}}$ & 5.8 & 5.0 & 5.5 & $5.5 \mathrm{~cd}$ & 5.0 & 5.5 & $4.8 \mathrm{~b}$ & $3.3 \mathrm{c}$ \\
\hline 2 & Fluopyram & 0.44 & A & 7.0 & 6.8 & 5.8 & 5.8 & $6.5 \mathrm{ab}$ & 5.5 & 4.8 & $7.0 \mathrm{a}$ & $7.8 \mathrm{ab}$ \\
\hline 3 & Fluopyram & 0.22 & $\mathrm{AB}$ & 7.0 & 7.0 & 6.0 & 6.3 & $7.0 \mathrm{a}$ & 5.3 & 5.5 & $7.8 \mathrm{a}$ & $7.5 \mathrm{~b}$ \\
\hline 6 & Fluopyram & 0.44 & E & 7.0 & 6.3 & 5.5 & 5.3 & $5.5 \mathrm{~cd}$ & 5.8 & 5.0 & $7.4 \mathrm{a}$ & $8.0 \mathrm{ab}$ \\
\hline 7 & Fluopyram & 0.22 & $\mathrm{EF}$ & 7.0 & 5.0 & 5.3 & 5.3 & $5.3 \mathrm{~d}$ & 5.8 & 5.8 & $7.3 \mathrm{a}$ & $8.5 \mathrm{a}$ \\
\hline
\end{tabular}

${ }^{\mathrm{z}} \mathrm{l} \mathrm{lb} / \mathrm{acre}=1.1209 \mathrm{~kg} \cdot \mathrm{ha}^{-1}$.

${ }^{y}$ Application timings: $\mathrm{A}=15$ Apr. 2015, B = 20 May 2015, C = 8 June 2015, D = 7 July 2015, E = 5 Aug. 2015, F= 3 Sept. 2015, G= 1 Oct. 2015 , H = 27 Oct. 2015, I=1 Dec. 2015 .

${ }^{\mathrm{x}} 1$ = dead; 6 = minimally acceptable quality; 9 = optimal color, density, texture, and uniformity.

${ }^{\text {w } M e a n s ~ w i t h i n ~ a ~ c o l u m n ~ f o l l o w e d ~ b y ~ t h e ~ s a m e ~ l e t t e r ~ o r ~ n o t ~ f o l l o w e d ~ b y ~ a n y ~ l e t t e r ~ a r e ~ n o t ~ s t a t i s t i c a l l y ~ d i f f e r e n t ~ a t ~} P \leq 0.05$ according to Fisher's protected least significant difference test.

Table 11. The impact of fluopyram on the number of pacific shoot-gall nematode (PSGN) galls counted per 100 shoots collected from an annual bluegrass putting green at Half Moon Bay Golf Links, Half Moon Bay, CA, in 2015.

\begin{tabular}{|c|c|c|c|c|c|}
\hline \multirow[b]{3}{*}{ No. } & \multirow[b]{3}{*}{ Treatment } & \multirow[b]{3}{*}{$\begin{array}{c}\text { Rate } \\
(\mathrm{lb} / \text { acre })^{\mathrm{z}}\end{array}$} & \multirow[b]{3}{*}{$\begin{array}{c}\text { Application } \\
\text { timing }^{\mathrm{y}}\end{array}$} & \multicolumn{2}{|c|}{ Sample collection date } \\
\hline & & & & 15 Apr. & 6 July \\
\hline & & & & \multicolumn{2}{|c|}{$\begin{array}{c}\text { PSGN galls } \\
\text { (no./100 shoots) }\end{array}$} \\
\hline 1 & Untreated & & & $4^{\mathrm{x}}$ & $9 \mathrm{a}$ \\
\hline 2 & Fluopyram & 0.44 & A & 2 & $0 \mathrm{~b}$ \\
\hline 3 & Fluopyram & 0.22 & $\mathrm{AB}$ & 3 & $0 \mathrm{~b}$ \\
\hline 4 & Fluopyram & 0.22 & B-I & 2 & $\mathrm{lb}$ \\
\hline 5 & Fluopyram & 0.44 & BCEF & 3 & $1 \mathrm{ab}$ \\
\hline
\end{tabular}

${ }^{\mathrm{z}} 1 \mathrm{lb} /$ acre $=1.1209 \mathrm{~kg} \cdot \mathrm{ha}^{-1}$.

${ }^{y}$ Application timings: A = 15 Apr. 2015, B = 20 May 2015, C = 8 June 2015, D = 7 July 2015, E = 5 Aug. 2015, F= 3 Sept. 2015, G = 1 Oct. 2015, $\mathrm{H}=27$ Oct. 2015, $\mathrm{I}=1$ Dec. 2015.

${ }^{\mathrm{x}}$ Means within a column followed by the same letter or not followed by any letter are not statistically different at $P \leq$ 0.05 according to Mann-Whitney $U$ test.

only occasional and mostly inconsistent improvements in turf. Among several botanical products, Crow (2005) tested an azadirachtin-containing pesticide in Florida turf trials. No noticeable influence of azadirachtin on plant-parasitic nematode populations or consistent performance improvement of treated turf was reported in his study.

The results of this study demonstrated the excellent efficacy of fluopyram as a new active ingredient against pacific shoot-gall nematode. The determination of an optimal rate and application frequency of fluopyram were not always apparent due to the conditions and availability of naturally infested putting green facilities. Still, often only one or two applications were sufficient to provide adequate disease control throughout a study period, which was nearly 1 year in most experiments. Fluopyram's half-life is reported as 180 to 360 d (New York State Department of Environmental Conservation, 2017). Therefore, it is likely to remain active for months on the annual bluegrass shoots and galls, which explains the efficacy of just one or two fluopyram applications. Although the effectiveness of fluopyram on reducing pacific shoot-gall disease was confirmed, the soil-dwelling populations of pacific shoot-gall nematode and the other plant-parasitic nematodes were rarely affected. This is in contrast to data reported from Florida where fluopyram proved effective against sting (Belonolaimus longicaudatus), root-knot, ring, and other plant- parasitic nematodes (Crow et al., 2017). The nematicide also had striking impacts on many other nonparasitic nematodes such as bacterivores, fungivores, and omnivores (Waldo et al., 2019). In the California trials, fluopyram applications were most likely not able to move past the putting greens' thatch layer and into the soil to significantly influence the plant-parasitic nematode populations. This is supported by research on the limited soil mobility of fluopyram that was influenced by soil physical characteristics (Faske and Brown, 2019). It can be hypothesized that most of the effective fluopyram applications remained on top of the thatch layer, covering the annual bluegrass grass stolons, flowers, and shoot bases. This zone remained nematicidal as being below the mowing height. Under conducive environmental conditions, temperatureand moisture-wise, soil-dwelling $\mathrm{J} 2$ of pacific shoot-gall nematode migrated up through that layer and were inhibited by the nematicide in moving onto annual bluegrass shoot surfaces toward the crown. Already infected shoots cannot be cured of the galls, but when an infected shoot died, its gall on the shoot base started decomposing. This opened the cavity to the containing infective J2 that migrated out and were eliminated by the nematicide. There was a delay of several weeks after the fluopyram application before the affected areas visually improved as the galled, dead shoots vanished, and their replacement new, healthy shoots established. 
Table 12. The impact of fluopyram on the number of pacific shoot-gall (PSGN), ring (RN), spiral (SN), and root-knot $(\mathrm{RKN})$ nematodes separated by species in $100 \mathrm{~mL}\left(6.1 \mathrm{inch}^{3}\right)$ of soil collected from an annual bluegrass putting green at Half Moon Bay Golf Links, Half Moon Bay, CA, in 2015-16.

\begin{tabular}{|c|c|c|c|c|c|c|c|c|c|}
\hline \multirow[b]{4}{*}{ No. } & \multirow[b]{4}{*}{ Treatment } & \multirow[b]{4}{*}{ Rate $(\mathrm{lb} / \text { acre })^{\mathrm{z}}$} & \multirow[b]{4}{*}{ Application timing ${ }^{y}$} & \multicolumn{6}{|c|}{ Sample collection date } \\
\hline & & & & \multicolumn{2}{|c|}{2015} & \multirow{2}{*}{$\frac{2016}{2 \mathrm{Feb} .}$} & \multicolumn{2}{|c|}{2015} & \multirow{2}{*}{$\frac{2016}{2 \mathrm{Feb} .}$} \\
\hline & & & & 15 Apr. & 6 July & & 15 Apr. & 6 July & \\
\hline & & & & \multicolumn{3}{|c|}{ PSGN (no./100 mL of soil) ${ }^{\mathrm{z}}$} & \multicolumn{3}{|c|}{ RN (no./100 mL of soil) } \\
\hline 1 & Untreated & & & $1038^{x}$ & 425 & $1242 \mathrm{a}$ & 68 & 81 & 21 \\
\hline 2 & Fluopyram & 0.44 & A & 909 & 28 & $0 \mathrm{~b}$ & 1511 & 51 & 69 \\
\hline 3 & Fluopyram & 0.22 & $\mathrm{AB}$ & 707 & 3 & $0 \mathrm{~b}$ & 982 & 68 & 52 \\
\hline 4 & Fluopyram & 0.22 & B-I & 931 & 238 & $0 \mathrm{~b}$ & 2791 & 90 & 37 \\
\hline 5 & Fluopyram & 0.44 & BCEF & 303 & 160 & $0 \mathrm{~b}$ & 1473 & 38 & 0 \\
\hline 6 & Fluopyram & 0.44 & $\mathrm{E}$ & 699 & - & $0 \mathrm{~b}$ & 594 & - & 47 \\
\hline \multirow[t]{2}{*}{7} & Fluopyram & 0.22 & $\mathrm{EF}$ & 1246 & 一 & $0 \mathrm{~b}$ & 1319 & - & 4 \\
\hline & & & & \multicolumn{3}{|c|}{$\mathrm{SN}($ no. $/ 100 \mathrm{~mL}$ of soil) } & \multicolumn{3}{|c|}{ RKN (no./100 mL of soil) } \\
\hline 1 & Untreated & & & $2433^{x}$ & 403 & 608 & 373 & 615 & 378 \\
\hline 2 & Fluopyram & 0.44 & A & 336 & 290 & 749 & 2298 & 1373 & 626 \\
\hline 3 & Fluopyram & 0.22 & $\mathrm{AB}$ & 226 & 270 & 763 & 665 & 1328 & 766 \\
\hline 4 & Fluopyram & 0.22 & B-I & 400 & 335 & 912 & 585 & 1235 & 809 \\
\hline 5 & Fluopyram & 0.44 & BCEF & 1678 & 260 & 367 & 1150 & 813 & 658 \\
\hline 6 & Fluopyram & 0.44 & E & 336 & - & 675 & 3178 & - & 882 \\
\hline 7 & Fluopyram & 0.22 & $\mathrm{EF}$ & 1158 & - & 611 & 3697 & - & 583 \\
\hline
\end{tabular}

Although fluopyram is known for its activity against various fungal pathogens (Veloukas and Karaoglanidis 2012), its efficacy as a fungicide could not be evaluated in our study. Fungal pathogens known to be controlled by fluopyram are not significant in this region and throughout most of California, and greens at each location were subjected to preventive fungicide programs. Therefore, no fungal pathogen activity was reported in our studies. This allowed our research to focus exclusively on the activity of fluopyram against pacific shoot-gall disease.

Although fluopyram has proven effective and long-lasting against pacific shoot-gall nematode-caused disease, in this and subsequent research (P.M. Orliński, P. Petelewicz, M Schiavon, J.O. Becker, and J.H. Baird, unpublished data), the frequent use of even the most effective pesticide is a recipe for a buildup of biodegrading microorganisms (Hugo et al., 2016) and against basic IPM guidelines. Reliance on only one active ingredient against a formidable pest like pacific shoot-gall nematode significantly increases the likelihood of developing resistance, especially given that resistance to fungal pathogens has been documented with fluopyram and other SDHI fungicides (Amiri et al., 2017; Popko et al., 2018; Sierotzki and Scalliet, 2013). The current development of several other effective nematicides with various modes of action promises the opportunity of rotating these novel tools to avoid overusing any single product.

\section{Literature cited}

Aerts, R.J. and A.J. Mordue (Luntz). 1997. Feeding deterrence and toxicity of neem triterpenoids. J. Chem. Ecol. 23:21172132, doi: 10.1023/B:JOEC.0000006433. 14030.04 .

Amiri, A., K.A. Mulvaney, L.K. Pandit, and D.R. Angelis. 2017. First report of resistance to fluxapyroxad and fluopyram in Botrytis cinerea from commercial apple orchards in Washington state. Plant Dis. 101:508, doi: 10.1094/PDIS-09-16-1384PDN.

Australian Pesticides and Veterinary Medicines Authority. 2015. Fenamiphos. Review findings report and regulatory decision. 14 Sept. 2020. <https://apvma. gov.au/sites/default/files/publication/ 15736 -fenamiphos-review-findingsreport.pdf $>$.
Barker, K.R. 1985. Nematode extraction and bioassays, p. 19-35. In: K.R. Barker, C.C. Carter, and J.N. Sasser (eds.). An advanced treatise on Meloidogyne. Volume 2: Methodology. U.S. Agency Intl. Dev., Raleigh, NC.

Becker, J.O., A. Ploeg, and J.J. Nuñez. 2019. Multi-year field evaluation of fluorinated nematicides against Meloidogyne incognita in carrots. Plant Dis. 103:2392-2396, doi: 10.1094/PDIS03-19-0489-RE.

Beeman, A.Q. and G.L. Tylka. 2018. Assessing the effects of ILeVO and VOTiVO seed treatments on reproduction, hatching, motility, and root penetration of the soybean cyst nematode, Heterodera glycines. Plant Dis. 102:107113, doi: 10.1094/PDIS-04-17-0585RE.

Cid Del Prado, V.I. and A.R. Maggenti. 1984. A new gall-forming species of Anguina Scopoli, 1777 (Nemata: Anguinidae) on bluegrass, Poa annua L., from the coast of California. J. Nematol. 16:386-392.

Costello, L. 1983. Parasitic nematode found in annual bluegrass greens. USGA Green Sect. Rec. 21:9-11.

Crow, W.T. 2005. Alternatives to fenamiphos for management of plant-parasitic nematodes on bermudagrass. J. Nematol. 37:477-482. 
Crow, W.T., J.O. Becker, and J.H. Baird. 2017. New golf course nematicides. Golf Course Manage. 85:66-71.

Faske, T.R. and K. Brown. 2019. Movement of seed-and soil-applied fluopyram in soil columns. J. Nematol. 51:1-8, doi: 10.21307/jofnem-2019-045.

Faske, T.R. and K. Hurd. 2015. Sensitivity of Meloidogyne incognita and Rotylenchulus reniformis to fluopyram. J. Nematol. 47:316-321.

Fleming, T.R., A.G. Maule, T. Martin, M. Hainon-McDowell, K. Entwistle, M.A. McClure, and C.C. Fleming. 2015. A first report of Anguina pacificae in Ireland. J. Nematol. 47:97-104.

Fungicide Resistance Action Committee. 2020. FRAC Code List 2020: Fungal control agents sorted by cross resistance pattern and mode of action (including FRAC Code numbering). 14 Sept. 2020. <https://www. frac.info/docs/default-source/publications/ frac-code-list/frac-code-list-2020finalbl6c2b2c512362eb9al eff00004acf5d. pdf?sfvrsn $=54 f 499 \mathrm{a} \_2>$.

Fürsch, H., H. Rieck, and J. Smedema. 2015. Velum ${ }^{\circledR}$-A novel nematicide for efficient crop production. XVIII Intl. Plant Protection Congr., Berlin, Germany. p. 41 (abstr.).

Giat, E., R. Kaspi, C.A. Anderson, and B.B. Westerdahl. 2008. Seasonal population dynamics of the plant-parasitic nematode, Anguina pacificae on golf course putting greens in California. J. Nematol. 40:252-257.

Hugo, H., C. Mouton, and A. Malan. 2016. Accelerated microbial degradation of nematicides in vineyard and orchard soils. S. Afr. J. Enol. Vitic. 35:157-167, doi: 10.21548/35-1-998.

Kandel, Y.R., K.A. Wise, C.A. Bradley, A.U. Tenuta, and D.S. Mueller. 2016. Effect of planting date, seed treatment, and cultivar on plant population, sudden death syndrome, and yield of soybean. Plant Dis. 100:1735-1743, doi: 10.1094/ PDIS-02-16-0146-RE.

Khalil, M.S. 2013. Abamectin and azadirachtin as eco-friendly promising biorational tools in integrated nematodes management programs. J. Plant Pathol. Microbiol. 4:174, doi: 10.4172/21577471.1000174.

Mitkowski, N.A. 2017. Nematodes on northern turfgrasses. Golfdom 73:32-35. 14 Sept. 2020. <https://www.golfdom.com/ nematodes-on-northern-turfgrasses $/>$.

Morris, K.N. and R.C. Shearman. 1999. NTEP turfgrass evaluation guidelines. Natl. Turfgrass Evaluation Program, Beltsville, MD.

New York State Department of Environmental Conservation. 2017. Re: Registration of the new active ingredient fluopyram as contained in four new pesticide products. 21 Aug. 2020. <http:// pmep.cce.cornell.edu/profiles/fungnemat/febuconazole-sulfur/fluopyram/ fluopyram_reg_0217.pdf>.

McClure, M.A., M.E. Schmitt, and M.D. McCullough. 2008. Distribution, biology and pathology of Anguina pacificae. J. Nematol. 40:226-239.

McClure, M.A. and M.E. Schmitt. 2012. A method for screening candidate nema- ticides against pacific shoot-gall nematode, Anguina pacificae. Nematropica 42:146-152.

Popko, J.T., Jr., H. Sang, J. Lee, T. Yamada, Y. Hoshino, and G. Jung. 2018. Resistance of Sclerotinia homoeocarpa field isolates to succinate dehydrogenase inhibitor fungicides. Plant Dis. 102:2625-2631, doi: 10.1094/PDIS-12-17-2025-RE.

Sierotzki, H. and G. Scalliet. 2013. A review of current knowledge of resistance aspects for the next-generation succinate dehydrogenase inhibitor fungicides. Phytopathology 103:880-887, doi: 10.1094/ PHYTO-01-13-0009-RVW.

Veloukas, T. and G.S. Karaoglanidis. 2012. Biological activity of the succinate dehydrogenase inhibitor fluopyram against Botrytis cinerea and fungal baseline sensitivity. Pest Manag. Sci. 68:858-864. doi: 10.1002/ps.3241.

Waldo, B.D., Z.J. Grabau, T.M. Mengistu, and W.T. Crow. 2019. Nematicide effects on non-target nematodes in bermudagrass. J. Nematol. 51:1-12, doi: 10.21307/ jofnem-2019-009.

Whitten, R. 2019. America's 100 greatest golf courses. 21 Aug. 2020. <https:// www.golfdigest.com/gallery/americas100-greatest-golf-courses-ranking $>$.

Wilen, C.A., A.J. Downer, A.M. Sutherland, B.B. Westerdahl, J.H. Baird, E.P. Caswell-Chen, D.W. Cudney, C.L. Elmore, M.L. Flint, M.A. Harivandi, and M. LeStrange. 2017. UC IPM pest management guidelines: Turfgrass. UC ANR Publ. 3365-T. 